UDC 616-053.2+613.2/.3: [614.31/638 (470.56)

DOI: $10.21668 /$ health.risk/2018.4.10.eng

\title{
RISK OF HEALTH DISORDERS IN CHILDREN CASUED BY CONSUMPTION OF CONTAMINATED FOOD PRODUCTS
}

\author{
A.G. Setko, J.K. Mryasova, A.V. Turin \\ Orenburg State Medical University, 6 Sovetskaya Str., Orenburg, 460000, Russian Federation
}

Prevalence of diseases related to chemical contamination of the environment, including food products, among various population group is still a vital issue. A child's body is the most sensitive to influences exerted by environmental contamination; deficiency of nutrients in a ration leads to a drastic increase in a risk of ecology-related health disorders. Our research goal was to hygienically assess safety of teenagers' and children's nutrition in Orenburg, taken in dynamics over 2007-2015, within risk assessment frameworks. Nutrition safety was assessed as per various food products groups. First of all, we focused on chemical contaminants; the priority ones that were identified included nitrates, heavy metals (lead, cadmium, mercury, arsenic, and copper), pesticides, chloramphenicol, and histamine. Laboratory analysis revealed the most contaminated products that included meat and meat products, milk and dairy products, fish and fish products, vegetative and animal oil. Dynamics taken over a long-term period allowed us to detect that a major contribution into a risk caused by chemical contamination was made by nitrates, mercury, cadmium, and arsenic. We determined non-carcinogenic hazards related to food products provided for nutrition in schools and pre-school children facilities; the first place belonged to impacts on the cardiovascular system, $H_{c v s}=4.99$; the second rank place was taken by impacts on the hormonal system, $H I_{\text {horm }}=4.56$; the third place belonged to impacts on the CNS, $H I_{c n s}=3.2$. Impacts on blood followed $\left(H I_{b l o o d}=3.18\right) ;$; they were followed by impacts on the immune system $\left(H I_{\text {immune }}=2.99\right)$, nervous system $\left(H I_{n e r v}=2.28\right)$, and kidneys $\left(H I_{\text {kidneys }}=2.28\right)$. When we assessed noncarcinogenic hazard indexes for nutrition outside children and teenagers facilities, we detected risks for the hormonal system $\left(H I_{\text {horm }}=2.8\right)$; $C N S\left(H I_{\text {cns }}=2.0\right)$; kidneys $\left(H I_{\text {kidneys }}=1.63\right)$; immune system $\left(H I_{\text {immune }}=1.58\right)$; reproductive system $\left(H I_{\text {repr }}=1.24\right)$; and the nervous system $\left(H I_{\text {nerv }}=1.17\right)$.

Total non-carcinogenic risk for critical organs and systems was assessed as "high" for the hormonal system (HI=7.4), CNS $(H I=5.2)$, and the cardiovascular system $(H I=5.8)$. Average non-carcinogenic risk was detected for the immune system $(H I=4.6)$ and the nervous system $(H I=3.5)$, for kidneys $(H I=3.9)$ and blood $(H I=3.6)$.

We detected changes in the microelement state of children and teenagers that were characterized with some parameters being higher than an average level in the country, namely as per lead contents (by $56 \%$ ), cadmium contents (by $87 \%$ ), mercury contents (by $30 \%$ ), and arsenic contents (by $23 \%$ ).

Key words: chemical contamination, health risk, children, nutrition safety, contaminants, non-carcinogenic risk.

Introduction. Nowadays quality and safety of food products are pressing issues and serious efforts are required to solve them, both by biochemists, microbiologists, and toxicologists, and by manufacturers and sanitary-epidemiologic authorities as well. As per data provided by the Federal Russian Institute of Nutrition, healthy nutrition can prevent up to $80 \%$ of cardiac infarctions, strokes, and diabetes [1, 2].

Food manufacturing technologies, chemistry, microbiology, and biotechnologies are constantly developing and it leads to creation of new food additives and GMOs that appear on the market in large quantities. And growing anthropogenic contamination of the environment calls for legal regulation performed by the state over relations in the sphere of providing food products safety and quality including sanitary-epidemiologic surveillance; when it is necessary, and especially when it concerns children nutrition, requirements to food products safety are to be toughened [3-8].

Nutrition is a key factor in preserving and improving population health; this postulate is

(C) Setko A.G., Mryasova J.K., Turin A.V., 2018

Andrey G. Setko - Doctor of Medical Sciences, Professor, head of Department for Children's and Teenagers' Hygiene and Nutrition and Occupational Hygiene (e-mail: a_isetko@mail.ru; tel.: +7 (3532) 50-06-06 (ext. 401); ORCID: https://orcid.org/0000-0002-4363-2169).

Jeanna K. Mryasova - full-time post-graduate student at the Department for Children and Teenagers Hygiene with Nutritional and Occupational Hygiene (e-mail: jane-very@mail.ru, tel.: +7 (3532) 50-06-06 (ext. 402)).

Alexander V. Turin - Candidate of Medical Sciences, Associate Professor at Department for DisastrousAccidents Medicine (e-mail: K GDiP@orgma.ru; tel.: +7 (3532) 50-06-06 (ext. 402); ORCID: https://orcid.org/0000-0002-5589-8116). 
fixed in the most significant state documents such as "The RF Food Security Doctrine" and "Fundamentals of the RF state policy in the sphere of healthy nutrition for a period up to 2020" [9]. Rospotrebnadzor presented the state viewpoint at the UN General Assembly on nutrition in September 2016 in New York: "when we solve issues related to sufficient and balanced nutrition, it is absolutely unacceptable to allow elevated health risks caused by microbiological and chemical contaminants in food products. Contemporary tools for risks assessment should give grounds for building up national strategies and plans aimed at fight against malnutrition in all its forms and at providing food safety and quality".

Special attention should be paid to the most vulnerable population groups, such as children and teenagers. A child body is highly sensitive to chemicals; multiple research proves that a share of children with various health disorders is substantially higher on urbanized territories. Recently there has been a negative trend related to increased burden of heavy metals $(\mathrm{Pb}, \mathrm{Cd}$, As, and $\mathrm{Hg})$ contained in food products on a child body [10-14]. Significant contamination of food products exerts negative impacts on proper functioning of systems in a growing child's body; it primarily influences the cardiovascular, hormonal, immune, nervous systems, and blood. Chemical contamination of food products exerts adverse impacts on children's physical development, causes strain in adaptation mechanisms and makes functional parameters go down [15-21].

Our research goal was to hygienically assess safety of basic food products used in nutrition provided for children and teenagers in Orenburg over 2007-2015 in terms of possible health risks that can be caused by them.

Data and methods. Safety of food products consumed by children and teenagers at their schools in Orenburg was assessed as per laboratory research data provided by Orenburg Regional Center for Hygiene and Epidemiology and according to MG 2.3.7.2125-06 "Social and hygienic monitoring. Chemical contamination of food raw materials and food products. Samples collection, processing, and analysis of parameters"1; experts checked whether food products conformed to standards fixed in the Customs Union Technical Regulations $^{2}$. Results of examinations performed on 5,106 food samples were analyzed in 8-year dynamics; all the samples were taken in Orenburg within scheduled inspections and examinations of food products safety. Non-carcinogenic risks caused by food products contaminated with chemicals was assessed according to the Guide R 2.1.10. 1920-04 "Guidelines on assessment of population health risk under exposure to chemicals which pollute environment ${ }^{3}$. Risk assessment was performed as per the complete chart and included four stages: hazard identification, assessment of exposure to chemicals, assessment of "dose response" relationship, and risk characteristics. Assessment of exposure assumed two exposure scenarios. The first scenario was aimed at assessing actual dose burdens borne by children at their schools, that is, it covered only food offered to children at educational establishments. The second scenario quantified exposure levels with determined concen-

\footnotetext{
${ }^{1}$ MG 2.3.7.2125-06. Social and hygienic monitoring. Chemical contamination of food raw materials and food products. samples collection, processing, and analysis of parameters [web-source] // KODEKS: an electronic fund of legal and reference documentation. - URL: http://docs.cntd.ru/document/1200048757 (date of visit June 16, 2018).

${ }^{2}$ CU TR 21/2011. On food products safety: The Customs Union Technical Regulations [web-source] // KODEKS: an electronic fund of legal and reference documentation. - URL: http://docs.cntd.ru/document/902320287 (date of visit June 16, 2018).

CU TR 033/2013. On safety of milk and dairy products: The Customs Union Technical Regulations [web-source] // KODEKS: an electronic fund of legal and reference documentation. - URL: http://docs.cntd.ru/document/499050562 (date of visit June 16, 2018).

CU TR 034/2013. On safety of meat and meat products: The Customs Union Technical Regulations [web-source] // KODEKS: an electronic fund of legal and reference documentation. - URL: http://docs.cntd.ru/document/499050564 (date of visit June 16, 2018).

${ }^{3} \mathrm{P}$ 2.1.10.1920-04. Guidelines on assessment of population health risk under exposure to chemicals which pollute environment. - M.: The Federal Center for the State Sanitary and Epidemiologic Surveillance of the RF Public Healthcare Ministry, 2004. $-143 \mathrm{P}$.
} 
trations and calculated doses of exposure to chemicals in food products sold in retail networks taking into account standard coefficients and calculation values as well as statistical data on consumption of basic food products. Risk characteristics for non-carcinogenic chemicals was calculated by comparing actual daily exposure (daily dose) with a reference dose or concentration; such characteristics also included calculating hazard quotient and hazard index that took into account impacts exerted by different chemicals on the same target systems and organs. When HQ (HI) was equal to 1 or lower it meant there was a negligible risk of hazardous impacts; when $\mathrm{HI}$ (HQ) was from 1 to 5, it meant a risk was average; when HI (HQ) was from 5 to 10 , a risk of non-carcinogenic effects was high.

Results and discussion. Food products contaminated with foreign chemicals can become a source of chronic contaminants accumulation in a body and lead to a decrease in quantities of essential substances due to oxidation. Such food products are actually hazardous as a growing child's body is extremely sensitive to penetration of abiogenous substances that produce adverse effects on a child's development and functioning of the most significant systems in a body, namely the immune, nervous, and genital ones. Nutrition safety was assessed as per 8 food products groups with such hazardous chemicals identified in them as nitrates, heavy metals $(\mathrm{Pb}, \mathrm{Cd}, \mathrm{Hg}$, $\mathrm{As}$, and $\mathrm{Cu})$, pesticides, chloramphenicol, and histamine.

We analyzed results of laboratory examinations and revealed that contamination levels differed in various food products groups. Thus, meat and meat products, milk and dairy products, fish and fish products, vegetable oil and butter were the most contaminated $(100 \%-$ $75 \%$ ); the next rank place belonged to fruit and vegetables, grain, sugar, and confectionary. The analysis allowed us to determine average daily doses of contaminants $(\mathrm{mg} / \mathrm{kg})$ consumed with food products and it substantiated assessment of non-carcinogenic risks for children's health.

According to the first exposure scenario, we assessed non-carcinoigenic risks caused by chemical contamination of food products consumed by children at their educational establishments. On average, 98-99\% children attending educational establishments in Orenburg were offered cooked meals and it allowed us to perform authentic assessment and minimize uncertainty errors.

We assessed non-carcinogenic risks caused by chemical contaminants consumed with food products in dynamics over a long period of time; the assessment results revealed that risk value as per priority contaminants was close to minimum over recent years $(\mathrm{HQ} \leq 1)$ (Figure 1). The greatest total noncarcinogenic hazard quotient was detected as per 1) nitrates that were mostly consumed with fruit, vegetables, meat, and meat products; 2) $\mathrm{Hg}$, mostly consumed with fish and fish products $(44 \%)$, fruit and vegetables $(22 \%)$, meat and meat products $(19 \%)$; 3$)$ As, mostly consumed with milk and dairy products, meat and meat products, fish and fish products $(43 \%, 23 \%$ and $18 \%$ respectively). The next rank place was taken by $\mathrm{Cd}$; this contaminant was mostly consumed with vegetable oil and butter, meat and meat products, fruit and vegetables $(45 \%, 29 \%$ and $13 \%$ respectively)

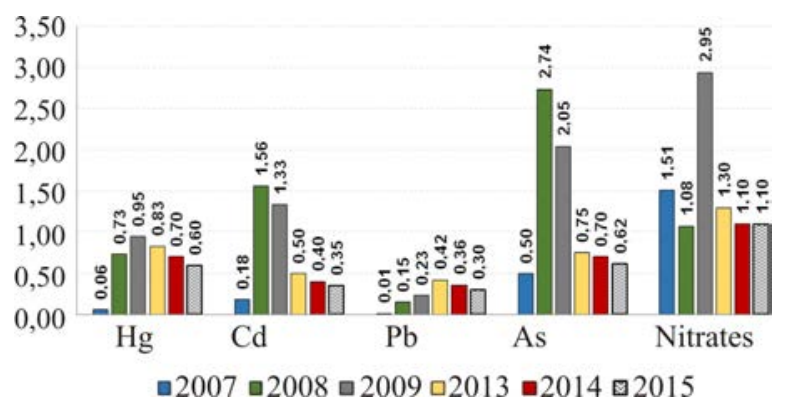

Figure 1. Dynamics of non-carcinogenic effects caused by contaminated food products consumed at educational establishments (HQ)

We calculated non-carcinogenic hazard indexes taking into account that different contaminants can exert their adverse impacts on the same target organs and systems. the greatest exposure risk was detected for the cardiovascular system $\left(H I_{\mathrm{cvs}}=4.99\right)$. The second rank place was taken by risk for the hormonal system $\left(H I_{\text {horm. }}=4.56\right)$; risk for the CNS took 
the third place $\left(H I_{\mathrm{cns}}=3.23\right)$. Risks for blood followed $\left(H I_{\text {blood }}=3.18\right)$; the next was risk for the immune system $\left(H I_{\text {immune }}=2.99\right)$, the nervous system (HInerv $=2.28)$, and kidneys $\left(H I_{\text {kidneys }}=2.28\right)$ (Figure 2$)$.

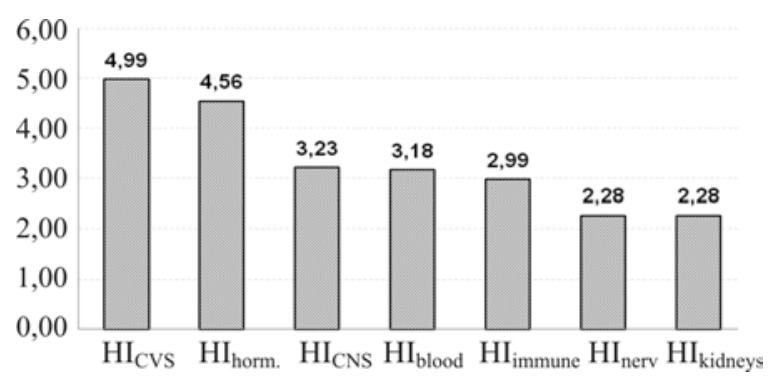

Figure 2. Total hazard indexes for critical organs and systems in a child's body calculated for children as per food consumed at their educational establishments $(H I)$

The second exposure scenario involved food consumed by children and teenagers beyond their educational establishments, that is, food consumed at home. Home meals satisfy from $40 \%$ to $60 \%$ of the overall daily need in nutrients and energy. In this scenario, exposure doses were calculated on the basis of examination results obtained for food products distributed through retail networks in the city, and safety and quality parameters as well; they were calculated as per a standard formula for calculating an average dose for food consumption in families with low middle incomes.

We assessed non-carcinogenic hazard indexes for meals consumed beyond educational establishments and detected that the first rank place belonged to risk of impacts on the hormonal system $\left(H I_{\text {horm. }}=2.8\right)$; the second one, risks for the CNS $\left(H I_{\mathrm{cns}}=2.0\right)$; the third one, risks to kidneys $\left(H I_{\text {kidneys }}=1.63\right)$; risks for other organs and systems followed (Figure 3). We should note that non-carcinogenic risks caused by meals consumed beyond educational establishments were 1.5-2 times lower than those caused by food consumed at such establishments.

Lower risks caused by consumption of chemicals with food products bought in retail outlets than those caused by food consumed at educational establishments are primarily ex- plained by poorer laboratory support provided for monitoring over quality and safety of food products; this poorer support doesn't allow to reduce errors of uncertainties in risk assessment. It is also confirmed by official statistic data on shares of food samples not conforming to hygienic standards as per chemical contaminants concentrations; they amounted to $0.64 \%$ in $2014,0.55 \%$ in 2015 , and $0.56 \%$ in 2016 in the RF in general, and to $0.1 \%, 0 \%$ and $0.06 \%$ in Orenburg respectively.

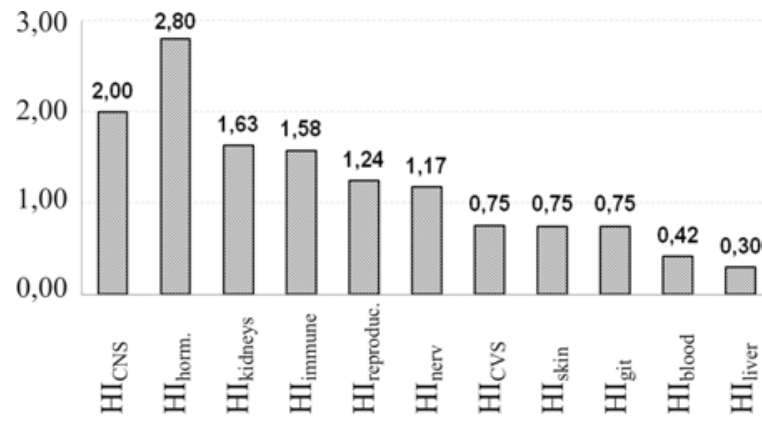

Figure 3. Total hazard indexes for critical organs and systems in a child's body calculated

for children as per food consumed beyond their educational establishments $(H I)$

At the next stage we assessed total noncarcinogenic risk for critical organs and systems caused by chemical contamination of food products, both consumed at educational establishments and distributed by retail networks in the city. We detected high risk for the hormonal system $(H I=7.4)$, the CNS $(H I=5.2)$, and the cardiovascular system $(H I=5.8)$. Average non-carcinogenic risks were detected for the immune system $(H I=4.6)$, the nervous system $(H I=35)$, kidneys $(H I=3.9)$, and blood $(H I=3.6)$ (Table).

There has been a growth in primary morbidity among children over the last 2-3 years at the population level; thus, morbidity with the circulatory system diseases has went up by $39.7 \%$; the nervous system diseases, by $24.3 \%$; neoplasms, by $8.9 \%$; injuries and intoxication, by $2 \%$; the respiratory system diseases, by $1.6 \%$; eye and its accessory apparatus diseases, by $1.3 \%$. Primary morbidity among teenagers has also grown as per several nosologies; morbidity with digestive organs 
Table

Risks of non-carcinogenic effects produced on children's health by chemicals consumed with food products

\begin{tabular}{|l|c|c|c|}
\hline $\begin{array}{c}\text { Critical organs } \\
\text { and systems }\end{array}$ & $\begin{array}{c}\text { Index of non-carcinogenic } \\
\text { hazard occurring beyond } \\
\text { educational establish- } \\
\text { ments } H I \text { (units) }\end{array}$ & $\begin{array}{c}\text { Index of non-carcinogenic } \\
\text { hazard occurring at educa- } \\
\text { tional establishments } H I \\
\text { (units) }\end{array}$ & $\begin{array}{c}\text { Total } \\
\text { non-carcinogenic } \\
\text { hazard index }(H I)\end{array}$ \\
\hline Central nervous system & 2.0 & 3.2 & 5.2 \\
\hline Hormonal system & 2.8 & 4.6 & 7.4 \\
\hline Kidneys & 1.6 & 2.3 & 3.9 \\
\hline Immune system & 1.6 & 3.0 & 4.6 \\
\hline Reproductive system & 1.2 & 0.0 & 1.2 \\
\hline Nervous system & 1.2 & 2.3 & 3.5 \\
\hline Cardiovascular system & 0.8 & 5.0 & 5.8 \\
\hline Skin & 0.8 & 0.0 & 0.8 \\
\hline Gastrointestinal tract & 0.8 & 0.0 & 0.8 \\
\hline Blood & 0.4 & 3.2 & 3.6 \\
\hline Liver & 0.3 & 0.0 & 0.3 \\
\hline
\end{tabular}

diseases has increased by $50.9 \%$; the nervous system diseases, by $40,6 \%$; blood and bloodmaking organs diseases, by $30.2 \%$; the musculoskeletal system diseases, by $13.7 \%$; ear and mastoid diseases, by $13.3 \%$; neoplasms, by $8.3 \%$; injuries and intoxications, by $6.2 \%$; the circulatory system diseases, by $0.9 \%$.

Conclusions. To sum up, we have detected that food products contamination causes high non-carcinogenic risks for the hormonal, cardiovascular, and central nervous systems in children and teenagers and it can lead to health disorders among these population groups.

Uncertainties in assessment of risks related to chemical contamination of food products consumed beyond educational establishments are 1.5-2 times higher than those occurring during assessment of nutrition provided for children and teenagers at their educational establishments due to qualitative laboratory control.

Given all the above-mentioned, we think it is necessary to update regulatory and methodical support for monitoring over quality and safety of food products as a part of social and hygienic monitoring as it will eventually allow to take into account all factors that influence validity of risk assessments.

Funding. The research was not granted any sponsor support.

Conflict of interests. The authors state there is no any conflict of interests.

\section{References}

1. Fetter V.V., Polyakov A.D. Comparative analysis of public health risk determined by chemical contamination of different types of food products. Health Risk Analysis, 2014, no. 2, pp. 55-67. DOI: 10.21668/health.risk/2014.2.07.eng (in Russian).

2. Fomina S.F., Stepanova N.V. Nekantserogennyi risk dlya zdorov'ya detskogo naseleniya g. Kazani, obuslovlennyi kontaminatsiei pishchevykh produktov i syr'ya [Non-carcinogenic risk to health of children population of Kazan, caused by contamination of food products and raw materials]. Aktual'nye voprosy obespecheniya sanitarno-epidemiologicheskogo blagopoluchiya naseleniya na urovne sub"ekta federatsii: Materialy mezhregional'noi nauchno-prakticheskoi internet-konferentsii [Vital issues related to providing sanitary-epidemiologic welfare of the population in a RF region: Materials collected at the regional theoretical and practical conference]. In: A.YU. Popova, N.V. Zaitseva, eds. Perm, 2017, pp. 236-243 (in Russian). 
3. Arnautov O.V. On improvement of the mechanism for establishing and changing indicators of quality and food safety in the regulatory and legal acts of the Eurasian Economical Union. Voprosy pitaniya, 2016, no. 1, pp. 110-116 (in Russian).

4. Bocharov E.P. Otsenka riska zdorov'yu naseleniya na territorii respubliki Tatarstan, svyazannogo s zagryazneniem produktov pitaniya [Assessment of population health risk related to food products contamination in the Republic of Tatarstan]. Voprosy pitaniya, 2015, vol. 84, no.S5, pp. 22 (in Russian).

5. Kon I.Ya., Konovalova L.S., Georgieva O.V. Issues of the support of the quality and safety of baby food. Gigiena i sanitariya, 2013, no. 1, pp. 36-39 (in Russian).

6. Kalinovskaya M.V., Litvinova O.S. Zaichenko, T.A., Sivokhina T.A. Sotsial'no-gigienicheskii monitoring kak instrument obespecheniya bezopasnosti pishchevoi produktsii v Rossiiskoi Federatsii [Social and hygienic monitoring as a tool for providing food products safety in the Russian Federation]. Rossiiskaya gigiena - razvivaya traditsii, ustremlyaemsya v budushchee: Materialy XII Vserossiiskogo $s^{\prime \prime}$ zda gigienistov i sanitarnykh vrachei, 17-18 noyabrya $2017 \mathrm{~g}$. [Russian Hygiene - we develop traditions and head for the future: Materials collected at the XII Russian Conference of hygienists and sanitary inspectors, held on November 17-18, 2017]. Moscow, 2017, pp. 80-82 (in Russian).

7. Onishchenko G.G. The Information on a sanitary-and-epidemiologic condition of general educational establishments and catering services of schoolboys. Voprosy pitaniya, 2008, no. 2, pp. 4-9 (in Russian).

8. Onishchenko G.G. Tasks and strategies of school nutrition in modern conditions. Voprosy pitaniya, 2009, vol. 78, no. 1, pp. 16-22 (in Russian).

9. Potoroko I. Ju., Popova N.V. State policy of Russia in the field of food safety and safety of foodstuff. Modern condition of the question. Vestnik yuzhno-ural'skogo gosudarstvennogo universiteta. Seriya: ekonomika i menedzhment, 2014, no. 21, pp. 92-98 (in Russian).

10. Setko A.G., Vyal'tsina N.E., Mryasova J.K., Plotnikova E.G. Risk zdorov'yu naseleniya, svyazannyi s upotrebleniem kontaminirovannykh pro-duktov pitaniya [Population health risk related to consumption of contaminated food products]. Rossiiskaya gigiena - razvivaya traditsii, ustremlyaemsya $v$ budushchee: Materialy XII Vserossiiskogo s"ez-da gigienistov i sanitarnykh vrachei [Russian Hygiene - we develop traditions and head for the future: Materials collected at the XII Russian Conference of hygienists and sanitary inspectors, held on November 17-18, 2017]. Moscow, 2017, pp. 167-170 (in Russian).

11. Setko I.M., Tymoshenko Evgenija, Setko A.G., Fateeva T.A. Feature microelement balance in the body school food contamination in heavy metal. Zdorov'e naseleniya i sreda obitaniya, 2013, no. 6, pp. 12-13 (in Russian).

12. Novikov S.M., Arutyunyan R.V., Shashina T.V., Sudakova E.V. [et al.]. Opyt otsenki kantserogennogo riska pri vozdeistvii khimicheskikh veshchestv, soderzhashchikhsya $\mathrm{v}$ pishchevykh produktakh [An experience of carcinogenic risk assessment under exposure to chemicals contained in food products]. Rossiiskaya gigiena - razvivaya traditsii, ustremlyaemsya $v$ budushchee: Materialy XII Vserossiiskogo $s^{\prime \prime} e z d a$ gigienistov $i$ sanitarnykh vrachei, 17-18 noyabrya $2017 \mathrm{~g}$. [Russian Hygiene - we develop traditions and head for the future: Materials collected at the XII Russian Conference of hygienists and sanitary inspectors, held on November 17-18, 2017]. Moscow, 2017, pp. 130-133 (in Russian).

13. Sergeev V.V., Klimushkin O.D., Il'ina E.V., Chernykh A.M. Otsenka riska vliyaniya khimicheskikh zagryaznitelei produktov pitaniya [Assessment of risks caused by chemical contaminants in food products]. Rossiiskaya gigiena - razvivaya traditsii, ustremlyaemsya v budushchee: Materialy XII Vserossiiskogo s"ezda gigienistov i sanitarnykh vrachei, 17-18 noyabrya $2017 \mathrm{~g}$. [Russian Hygiene - we develop traditions and head for the future: Materials collected at the XII Russian Conference of hygienists and sanitary inspectors, held on November 17-18, 2017]. Moscow, 2017, pp. 164-167 (in Russian).

14. Pokrovskii A.A. Metabolicheskie aspekty farmakologii i toksikologii pishchi [Metabolic aspects of food pharmacy and toxicology]. Moscow, Meditsina Publ., 1987, 181 p. (in Russian).

15. Ivanova I.L., Kislitsyna L.V. The impact of contaminated food on the incidence of digestive diseases of the population in the Primorsky territory. Zdorov'e. Meditsinskaya ekologiya. Nauka, 2014, vol. 58, no. 4, pp. 85-88 (in Russian). 
16. Kislitsyna L.V., Ivanova I.L., Kiku P.F. Estimation of risk of the likely impact of heavy metals in food on health of population of the Primorsky region. Zdorov'e. Meditsinskaya ekologiya. Nauka, 2015, vol. 62, no. 4, pp. 78-83 (in Russian).

17. Stepanova N.V., Fomina S.F., Valeeva E.R. Gigienicheskaya otsenka bezopasnosti pitaniya naseleniya Respubliki Tatarstan [Hygienic assessment of nutrition safety for population in the Republic of Tatarstan]. Voprosy pitaniya, 2016, vol. 85, no. S2, pp. 36-37 (in Russian).

18. Sorokina A.V., Giguz T.L., Polyakov A.Ya., Bogachanov N.D. Hygienic assessment of actual nutrition of children of school age as a risk factor for the formation of morphological and functional abnormalities. Zdorov'e naseleniya i sreda obitaniya, 2017, vol. 286, no. 1, pp. 27-30 (in Russian).

19. Kon I.Ya., Volkova L.Yu., Dimitrieva S.A. Aktual'nye problemy organizatsii pitaniya shkol'nikov [Vital issues related to organization of nutrition for children]. Zdorov'e naseleniya $i$ sreda obitaniya, 2009, vol. 194, no. 5, pp. 4-8 (in Russian).

20. Kuchma V.R., Rapoport I.K., Gorelova Zh.Yu. Nauchno-organizatsionnye osnovy mo-nitoringa realizatsii eksperimental'nykh proektov po sovershenstvovaniyu organizatsii pitaniya obuchayushchikhsya v GOU sub"ektov Rossiiskoi Federatsii i munitsipal'nykh obshcheobrazovatel'nykh uchrezhdeniyakh [Scientific and organizational grounds for monitoring and implementation of experimental projects aimed at updating organization of nutrition for schoolchildren in the RF regional and municipal educational establishments]. Zdorov'e naseleniya i sreda obitaniya, 2009, no. 5, pp. 9-11 (in Russian).

21. Kuchma V.R., Rapoport I.K., Gorelova Zh.Yu. Monitoring the realization of of experimental projects aimed at improvement of school alimentation in secondary school institutions in the regions of the russian federation and in municipal educational institutions. Zdorov'e naseleniya i sreda obitaniya, 2009, no. 8, pp. 27-29 (in Russian).

Setko A.G., Mryasova J.K., Turin A.V. Risk of health disorders in children casued by consumption of contaminated food products. Health Risk Analysis, 2018, no. 4, pp. 89-95. DOI: 10.21668/health.risk/2018.4.10.eng

Received: 05.03.2018

Accepted: 24.10 .2018

Published: 30.12 .2018 